Indonesian Journal of Physics and Nuclear Applications

Volume 2, Number 3, October 2017, p. 111-123

e-ISSN 2550-0570, (C) FSM UKSW Publication

\title{
DOSE ANALYZE OF BORON NEUTRON CAPTURE THERAPY (BNCT) AT SKIN CANCER MELANOMA USING MCNPX WITH NEUTRON SOURCE FROM THERMAL COLUMN OF KARTINI REACTOR
}

\author{
Siti Rosidah $^{1 *}$, Yohannes Sardjono ${ }^{2}$, Yosaphat Sumardi ${ }^{1}$ \\ ${ }^{1}$ Department of Physics - Mathematics and Sains Faculty UNY \\ ${ }^{2}$ Center of Accelerator and Material Process Technology- BATAN \\ *Email:sitirosidah203@gmail.com
}

\begin{abstract}
This research aims to determine the amount of radiation dose rate that can be accepted and the irradiation time that is required from Boron Neutron Capture Therapy (BNCT) cancer therapy to treat melanoma skin cancer. This research used the simulation program, MCNPX by defining the geometric dimensions of the tissue component, and describing the radiation source that were used. The outputs obtained from the MCNPX simulation were the neutron flux and the neutron scattering dose that came out from the collimator. The value of neutron flux was used to calculate the dose which comes from the interaction between the neutron and the material in the cancer tissue. Based on the results of the research, the dose rate to treat cancer tissue for boron is $10 \mu \mathrm{g} / \mathrm{g}$ of tumor, which translates to about $0.019241 \mathrm{~Gy} / \mathrm{second}$ and requires 25.98 minutes of irradiation time, $15 \mu \mathrm{g} / \mathrm{g}$ of tumor translates to $0.021854 \mathrm{~Gy} / \mathrm{second}$ and requires $2 ., 87 \mathrm{minutes}, 20 \mu \mathrm{g} / \mathrm{g}$ of tumor translates to $0.022902 \mathrm{~Gy} / \mathrm{second}$ and requires 21,83 minutes, $25 \mu \mathrm{g} / \mathrm{g}$ of tumor translates to 0.0271275 $\mathrm{Gy} / \mathrm{second}$ and requires 18.43 minutes, $30 \mu \mathrm{g} / \mathrm{g}$ of tumor translates to $0.0297658 \mathrm{~Gy} / \mathrm{second}$ and requires $16.79 \mathrm{minutes}$, and $35 \mu \mathrm{g} / \mathrm{g}$ of tumor translates to $0.0343472 \mathrm{~Gy} / \mathrm{second}$ and requires 14.55 minutes. The irradiation time needed for cancer tissue is shorter when boron concentration greater at the cancerous tissue.
\end{abstract}

Keywords BNCT, MCNPX, Skin Cancer, Melanoma.

\section{INTRODUCTION}

Melanoma is a cancer that starts in a particular type of skin cell. To understand melanoma, it is beneficial to understand the normal structure and function of the skin. Melanoma is a cancer that begins in melanocytes. Other names for this cancer include malignant melanoma and cutaneous melanoma. Most melanoma cells still make melanin, so melanoma tumors are usually brown or black. But some melanomas do not make melanin and can appear pink, tan, or even white. [1]

Current methods of cancer therapy include surgery or surgical methods, chemotherapy, and radiotherapy. Surgical methods involve the removal of cancerous tissue. Chemotherapy is a cancer therapy that uses drugs to kill cancer cells. Radiotherapy is a cancer therapy that uses particles or high-energy waves such as X-rays to kill cancer cells (American Cancer Society, 2015). This method utilizes ionization properties generated by sources in areas exposed to radiation exposure. The source of radiation can come from outside the body (external) or from within the body (internally) by an implant or embedded radioactive sources.

Along with the development of technology, a safe radiotherapy method for cancer therapy, named Boron Neutron Capture Therapy (BNCT) is being developed.

Boron Neutron Capture Therapy (BNCT) is 
based on the ability of the non-radioactive isotope boron-10 to capture thermal neutrons. This nuclear reaction produces two high-LET particles (He-4 and Li-7) with a tissue range that is limited to the diameter of a single cell. This offers the possibility to target single tumor cells and to destroy them with high efficiency while sparing other healthy tissues containing less boron-10[2].

\section{LITERATUR REVIEW}

Melanoma skin cancer is a type of skin cancer caused by the uncontrolled growth of melanocyte cells due to DNA damage. Melanoma is a rare type of skin cancer, but is more deadly than other types of skin cancer. That is because melanoma's ability to metastasize to other organs is greater so that it causes the most deaths out of all skin cancer cases. Most melanomas will still produce melanin; therefore, melanoma skin cancer is usually brown or black.

Melanoma can occur in all areas of the skin. In men it is usually found on the chest or back while in women it is usually found on the legs. However, melanomas can also be found on the face, neck, palms, soles of the feet, or under the nails. Melanoma is more common in people who have bright skin tones and are rarely found in dark-skinned people. Some of the following are the causes of a person being exposed to melanoma (American Cancer Society, 2016).

BNCT combines the principles of chemotherapy and radiotherapy. The chemotherapy principle is due to the presence of boron-10, Sodium Boronocaptate (BSH) or Boronophenylalanine (BPA) compounds which are inserted into the patient's body first. The radiotherapy principle is included because the patient is later irradiated with a neutron source. Another advantage of BNCT is that the boron compound at a certain concentration is not toxic. The time interval between the administration of the boron compound and the neutron irradiation can be determined to optimize the ratio concentration of boron in the cancerous tissue and the boron in the healthy tissue. Only the tissue located around the cancerous tissue exposed to the effects of neutron irradiation and boron-10 need to be considered. Another reason for the selection of boron- 10 is that it has a greater thermal neutron uptake than any other element in the body.

Table 1. Comparison of Mid-Thermal Neutron Capture Views Multiple Elements (Soppera et al, 2012; Sauerwein, 2012)

\begin{tabular}{|c|l|l|}
\hline Element & \multicolumn{1}{|c|}{ Mass (\%) } & $\begin{array}{c}\text { Cross Section } \\
\text { (barns) }\end{array}$ \\
\hline Hidrogen & 10,5 & 32,945 \\
\hline Oksigen & 63,5 & 4,4814 \\
\hline Nitrogen & 2,5 & 13,481 \\
\hline Karbon & 22,6 & 5,576 \\
\hline Kalsium & 1,43 & 0,41 \\
\hline Boron-10 & - & 3835 \\
\hline
\end{tabular}

In BNCT, there are three important factors that must be considered for cancer therapy with this method can be successful. These factors are the sources of neutrons used in irradiation, the boron compounds administered to the patient, and the resulting radiation dose.

Table 2. Kriteria Sumber Neutron (IAEA, 2001; Fauziah, 2013)

\begin{tabular}{|c|c|c|c|}
\hline $\begin{array}{c}\text { Para } \\
\text { meter }\end{array}$ & $\begin{array}{c}\text { Notation } \\
\text { (satuan) }\end{array}$ & $\begin{array}{c}\text { IAEA } \\
\text { Recommen } \\
\text { dation } \\
\end{array}$ & $\begin{array}{c}\text { Collimator } \\
\text { Output }\end{array}$ \\
\hline $\begin{array}{l}\text { Epitherma } \\
1 \text { neutron } \\
\text { flux }\end{array}$ & $\begin{array}{c}\emptyset_{\mathrm{epi}} \\
\left(n c m^{-2} s^{-1}\right)\end{array}$ & $>1,0 \times 10^{9}$ & $1,65 \times 10^{9}$ \\
\hline $\begin{array}{l}\text { Rapid } \\
\text { neutron } \\
\text { dose } \\
\text { rate/epithe } \\
\text { rmal } \\
\text { neutron } \\
\text { flux }\end{array}$ & $\begin{array}{c}\dot{\mathrm{D}}_{\mathrm{f}} / \emptyset_{\mathrm{epi}} \\
\left(G y c m^{2} n^{-1}\right)\end{array}$ & $<2,0 \times 10^{-13}$ & $1,59 \times 10^{-13}$ \\
\hline $\begin{array}{l}\text { Epidermal } \\
\text { neutron } \\
\text { gamma }\end{array}$ & $\begin{array}{c}\dot{\mathrm{D}}_{\gamma} / \emptyset_{\mathrm{epi}} \\
\left(G y c m^{2} n^{-1}\right)\end{array}$ & $<2,0 \times 10^{-13}$ & $1,16 \times 10^{-13}$ \\
\hline
\end{tabular}




\begin{tabular}{|l|c|c|c|}
\hline \multicolumn{1}{|c|}{$\begin{array}{c}\text { Para } \\
\text { meter }\end{array}$} & $\begin{array}{c}\text { Notation } \\
\text { (satuan) }\end{array}$ & $\begin{array}{c}\text { IAEA } \\
\text { Recommen } \\
\text { dation }\end{array}$ & $\begin{array}{c}\text { Collimator } \\
\text { Output }\end{array}$ \\
\hline $\begin{array}{l}\text { dose } \\
\text { rat/flux } \\
\text { density }\end{array}$ & & & \\
\hline $\begin{array}{l}\text { Epidermal } \\
\text { neutron } \\
\text { gamma } \\
\text { dose } \\
\text { rate/flux } \\
\text { density }\end{array}$ & $\emptyset_{\text {th }} / \emptyset_{\text {epi }}$ & $<0,05$ & 0,007 \\
\hline $\begin{array}{l}\text { The ratio } \\
\text { between } \\
\text { the } \\
\text { neutron } \\
\text { current } \\
\text { and the } \\
\text { neutron } \\
\text { flux }\end{array}$ & $\mathrm{J} / \emptyset_{\mathrm{epi}}$ & $<0,7$ & 0,72 \\
\hline
\end{tabular}

The Kartini Reactor is used as the neutron source in this study. Neutrons are passed through a conceptually designed collimator. A conceptual design of a collimator on the Kartini Reactor thermal column is made from several materials (Fauziah, 2013), as shown in Fig. 5 with the following sizes:

1) $\mathrm{Ni}$, with a thickness of $5 \mathrm{~cm}$ as a wall of the collimator,

2) $\mathrm{Al}$, with a thickness of $60 \mathrm{~cm}$ as a moderator,

3) ${ }^{60} \mathrm{Ni}$, with a thickness of $15 \mathrm{~cm}$ as a filter

4) $\mathrm{Bi}$, with a thickness of $2 \mathrm{~cm}$ as a gamma ray shield

5) ${ }^{6} \mathrm{Li}_{2} \mathrm{CO}_{3}$-polietilen, with a thickness of 3 $\mathrm{cm}$ as a neutron radiation barrier

There two boron compounds used in BNCT, BSH (Sodium borocaptate, Na210B12H11SH) and BPA (Boronophenylalanine, C9H1210BNO4). Both compounds accumulate at different locations. BSH will accumulate on the cell membrane and BPA will accumulate on the cell nucleus.

The boron compound that is already being used in clinical testing is BPA. Concentration of BPA in melanoma cancer cells have been observed to be about 1.6 times than in normal melanocyte cells. In addition, boron-10 concentrations in cancer cells increased in the 90th minute and were maximal at the 150 minutes' mark after injection into the body (Flores et al., 2012).

In BNCT, there are four components of the dose that needs to be considered.

\section{1) Dose of Gamma (D $\gamma)$}

The dose of gamma in the BNCT dose component comes from the reaction between hydrogen-1 in body tissues and thermal neutrons. The reaction produces gamma and hydrogen-2 particles. The resulting hydrogen-2 is an excited atom, so it does not have a half-life. The resulting gamma particle has an energy of $2.33 \mathrm{MeV}$. The following is a reaction equation between hydrogen-1 and thermal neutrons (IAEA, 2001; Sauerwein, 2012).

$$
{ }_{1}^{1} \mathrm{H}+{ }_{1}^{1} \mathrm{n}(0,025 \mathrm{eV}) \rightarrow{ }_{1}^{2} \mathrm{H}+\gamma(2,33 \mathrm{MeV})(2)
$$

2) Dose of Neutron Scattering (Dn)

The neutrons produced by the reactor are not only thermal neutrons, but also fast neutrons. The interaction between neutrons and matter can produce recoil and photon radiation. The interaction that will occur is the neutron scattering reaction. It is characterized by the value of cross-sectional coefficient scattering on body tissues (IAEA, 2001; Sauerwein, 2012).

\section{3) Dose of Proton (DP)}

The dose of proton in the BNCT dose component is derived from the reaction between the thermal neutron and the nitrogen element in the body. The reaction will result in a carbon recoil and proton having an energy of $0.66 \mathrm{MeV}$ (IAEA, 2001; Sauerwein, 2012). The following is the reaction equation between thermal neutrons 
and nitrogen.

$$
{ }_{7}^{14} \mathrm{~N}+{ }_{0}^{1} \mathrm{n}(0,025 \mathrm{MeV}) \rightarrow{ }_{6}^{14} \mathrm{C}+{ }_{1}^{1} \mathrm{p}(0,66 \mathrm{MeV})
$$

4) Dose of Boron (DB)

The boron dose is derived from the interaction between the thermal neutron and the boron compound injected into the cancerous tissue. The reactions between boron and thermal neutrons can be seen in equation 1. The reaction between a thermal neutron and boron-10 in tissue have the highest probability of occurring because boron has a high thermal neutron catch crossover when compared to other elements, which is 3835 barn

The Kartini Reactor (TRIGA MARK-II Reactor), located at the Center for Research on Pure and Instrumentation Materials (PPBMI) BATAN Yogyakarta, is one of three nuclear reactors in Indonesia.

The Kartini reactor is a source of neutron radiation that is used for irradiation of melanoma on skin cancer patients. It produces not only thermal and epithermal neutrons but produces fast neutrons also. Regarding fast neutrons, there are other undesirable radiation beams due to its character, such as protons with high LET and free radicals (IAEA, 2001). This results in the need for a weight factor or radiation quality factor, so that the total dose received by organs is:

$$
D_{T}=w_{\gamma} D_{\gamma}+w_{n} D_{n}+w_{p} D_{p}+w_{B} D_{B}
$$

Monte Carlo N-Particle (MCNP) is a particle transport analysis software and radiation transfer that uses a stochastic method called Monte Carlo. This software was developed by Los Alamos National Laboratory. MCNP software is continually being developed since its creation in 1940. The latest version is Monte Carlo N-Particle eXtended (MCNPX). This version is also continually being developed since its creation in 1994. MCNPX 2.6.0 is the last computer code released by the Radiation Safety Information Computational Center (RSICC).

MCNPX uses continuous nuclear energy and nuclide data. The main sources of nuclear data are the evaluation data of the ENDF (Evaluated Nuclear Data File) system, the ACTI (Advanced Computational Technology Initiative), the EPDL (Evaluated Data Photon Library), the Livermore ACTL (The Activation Library), and the evaluation of Nuclear Physics ( T-16) Group 6, 7, 8 Los Alamos. MCNPX has capabilities that allow the user to specify the source conditions without having to make modifications to the whole code. MCNPX users can create input files for processing based on the desired calculations. This input file consists of geometry specification, material description, location of the neutron source, and the desired type of tally. Tally shows the information the user wants to collect. Tally MCNPX normalized per particle early, except in some special cases that have a critical source. The following is a tally provided by MCNPX (Booth, 2003; Muslih, 2014).

\section{MATERIALS AND METHODS}

This research is a simulated study using MCNPX on melanoma skin cancer with a neutron source from a collimator design on the Kartini Reactor thermal column to find the dose value of BNCT and the time of irradiation necessary to kill the cancerous tissue. This research uses free variable in the form of boron concentration included in cancer tissue.

This research was conducted in September 2014 until December 2014 at the Accelerator and Materials Process Center of National Nuclear Energy Agency (PTAPB-BATAN) Yogyakarta. Research was conducted through the making of a source code for MCNPX which contains data of 
geometric specification and material specifications of melanoma type cancer.

This study uses a MCNPX-code with the Kartini Reactor as a neutron source which is accomplished by first collecting literature on skin cancer, especially skin cancer melanoma. In addition to collecting literature on melanoma skin cancer, literature on BNCT, Kartini Reactor, and MCNPX was also gathered. The next stage was to learn all the literature that had been collected and choose the type of skin cancer and its position.

Followed by that, the volume of cancer cells and other tissues were counted. This is necessary because the tally used in this study requires volume input. After the organ geometry and collimator forms are completed, the next stage is to vary the boron in the atomic fraction part of the constituent material. We used 6 variations of boron, i.e. $10 \mu \mathrm{g} / \mathrm{g}$ cancer, $15 \mu \mathrm{g} / \mathrm{g}$ cancer, $20 \mu \mathrm{g} / \mathrm{g}$ cancer, $25 \mu \mathrm{g} / \mathrm{g}$ cancer, $30 \mu \mathrm{g} / \mathrm{g}$ cancer, and $35 \mu \mathrm{g} / \mathrm{g}$ of cancer. Once the specifications are ready, the MCNPX input code can be completed, therefore the next stage is running MCNPX with a command prompt application (cmd) to get thermal and epithermal neutron flux. The next step is to calculate the BNCT dose using Ms. Application Excel. Then analyze the data and graphs using the application origin 6.1 and draw conclusions from the research.

The dose calculation for BNCT consists of four parts according to the neutron interaction that occurs. BNCT dose components include an alpha dose, a gamma dose from reactors and interaction with matter, a proton dose, and a neutron scattering dose. The results of the MCNPX code that can be used directly is the rate of gamma dose from the reactor and the dose of neutron scattering.
The analysis is then continued by performing calculations using the Microsoft Excel application in accordance with the following steps:

\section{Calculation of the Number of Atoms in Tissue}

The number of atoms in a tissue indicates a possible reaction between neutrons and compounds during the irradiation process. The number of atoms in the network $\left(\mathrm{N}_{\mathrm{i}-\text { tissue }}\right)$ can be obtained by dividing the atomic number $\left(\mathrm{N}_{\mathrm{i}}\right)$ value of an element on a tissue with a mass of tissue (by $\mathrm{kg}$ unit) or can be written in the following equation (Berlianti, 2013):

$$
\mathrm{N}_{\mathrm{i}-\text { tissue }}=\frac{\mathrm{N}_{\mathrm{i}} \text { (atom) }}{\mathrm{m}_{\text {tissue }}(\mathrm{kg})}
$$

The value of the number of atoms can be obtained by multiplying the mole value of an element $\left(\mathrm{n}_{\mathrm{i}}\right)$ with the Avogadro number $\left(\mathrm{N}_{\mathrm{A}}=\right.$ $6,023 \times 10^{23}$ atom $/ \mathrm{mol}$ ), written in the following equation (Berlianti, 2013:

$$
\mathrm{N}_{\mathrm{i}}=\mathrm{n}_{\mathrm{i}} \mathrm{N}_{\mathrm{A}}
$$

The mole value of an element is the result of the distribution of the mass of an element $\left(\mathrm{m}_{\mathrm{i}}\right)$ with the relative atomic mass $\left(A_{r}\right)$ of that element, written in the following equation (Berlianti, 2013):

$$
\mathrm{n}_{\mathrm{i}}=\frac{\mathrm{m}_{\mathrm{i}}(\text { gram })}{\mathrm{A}_{\mathrm{r}}\left(\frac{\text { gram }}{\mathrm{mol}}\right)}
$$

\section{Calculation of Dose Rate}

The rate of the components to be calculated manually has a difference in equation to that used. Calculations to be performed are:

a. Gamma dose rate (thermal neutron reaction that results with hydrogen-1).

The reaction between thermal neutrons and hydrogen-1 following equation 2, yields a 2.23 $\mathrm{MeV}$ gamma particle. Calculation of the 
deuterium formation rate is done because the rate of gamma formation in this reaction is equal to the rate of deuterium formation. The rate of gamma formation is calculated by the following equation (Berlianti, 2013; Irhas, 2014):

$$
\dddot{\mathrm{R}}=\emptyset \mathrm{N}_{\mathrm{H}-\text { tissue }} \sigma_{\mathrm{H}}
$$

With as the rate of formation of deuterium (hydrogen-2) or the rate of gamma particles being released, its units are photon $/ \mathrm{kg} . \mathrm{s}=\mathrm{Bq} / \mathrm{kg} ; \varnothing$ is a thermal neutron flux, which has a neutron. $\mathrm{cm}^{-2} \cdot \mathrm{s}^{-1}$; is the number of hydrogen atoms per $\mathrm{kg}$ of tissue, its units are $/ \mathrm{kg}$; And $\sigma_{-} \mathrm{H}$ is the cross-sectional thermal neutron uptake of hydrogen, its units are $\mathrm{cm}^{2}$.

The gamma-absorbing dose fraction is a coefficient that shows the dose the tissue receives from a given gamma radiation energy. Determination of the dose rate for gamma particles $(\mathrm{D} \gamma)$ on the network is determined by the following equation (Berlianti, 2013; Irhas, 2014):

$$
\dot{D_{\gamma}}=\dddot{R} \Delta \varphi
$$

$(\mathrm{D} \gamma)$ is the rate of gamma dose, its units are $\mathrm{Gy} / \mathrm{s} ; \Delta$ is the coefficient of absorptive dose rate/gamma specific activity from CGS to SI unit $\left(1.6 \times 10^{-13} \times 2.33 \mathrm{MeV} /=3.568 \times 10^{-13}\right)$; And $\varphi$ is a gamma-absorbing dose fraction (determined by looking at attachment 4 ).

b. The rate of proton dose (thermal neutron reaction results with nitrogen-14)

The proton dose rate comes from a thermal neutron catch reaction with nitrogen-14, which produces a carbon- 14 and a $0.66 \mathrm{MeV}$ energy proton. From that reaction, the proton dose rate is determined by the following equation (Berlianti, 2013; Irhas, 2014):

$$
\dot{D} \text { proton }=\frac{\emptyset \mathrm{N}_{\mathrm{N}-\text { jaringan }} \sigma_{\mathrm{a}, \mathrm{N}} \mathrm{Q} 1,6 \times 10^{-13} \mathrm{~J} / \mathrm{MeV}}{1 \frac{\mathrm{J} / \mathrm{kg}}{\mathrm{Gy}}}
$$

Diproton is the rate of proton dose, its units are $\mathrm{Gy} / \mathrm{s} ; \varnothing$ is a thermal neutron flux, which has a neutron. $\mathrm{cm}^{-2} \cdot \mathrm{s}^{-1} ; \mathrm{N}_{\mathrm{N} \text {-tissue }}$ is the number of nitrogen atoms-14 per $\mathrm{kg}$ of tissue, its units are unit/kg of tissue; $\sigma_{\mathrm{a}, \mathrm{N}}$ is a nitrogen-14 microscopic latitude cross, its units are $\mathrm{cm}^{2}$; And $\mathrm{Q}$ is the energy of the particle, its units are $\mathrm{MeV}$. c. Alpha dose rate (thermal neutron reaction result with boron-10)

The alpha dose rate is obtained from the reaction between the thermal neutron and boron10 , according to equation 1 . The reaction yields an alpha particle with a mean energy of 2.33 $\mathrm{MeV}$. Calculation for the alpha dose rate uses the following equation (Berlianti, 2013; Irhas, 2014):

$$
\dot{D} \text { alfa }=\frac{\emptyset \mathrm{N}_{\mathrm{B}-\mathrm{tissue}} \sigma_{\mathrm{a}, \mathrm{B}} \mathrm{Q} 1,6 \times 10^{-13} \mathrm{~J} / \mathrm{MeV}}{1 \frac{\mathrm{J} / \mathrm{kg}}{\mathrm{Gy}}}
$$

Dalfa is the alpha dose rate, its units are $\mathrm{Gy} / \mathrm{s} ; \varnothing$ is a thermal neutron flux, which has a neutron. $\mathrm{cm}^{-2} . \mathrm{s}^{-1} ; \mathrm{N}_{\mathrm{B}-\text { tissue }}$ Is the number of boron atoms-10 per $\mathrm{kg}$ of tissue, its units are $/ \mathrm{kg}$ of tissue; $\sigma_{\mathrm{a}, \mathrm{B}}$ is a microscopic cross-sectional absorption of boron-10 its units are $\mathrm{cm} 2$; And Q is the energy of the particle, its units are $\mathrm{MeV}$.

\section{d. Total dose rate}

The total dose rate analyzed in this study has the same principle as the equivalent dose in radiation protection. The equivalent dosage is a dose distribution especially used in radiation protection and states the extent of damage to tissues due to the absorption of some radiation energy by considering the factors that influence it. The equivalent dose is obtained by multiplying the absorbing dose by the radiation weight factor. Radiation weight factor is a coefficient that shows the destructive capability of radiation. Calculation of total dose rate is done using the 
following equation (Berlianti, 2013; Irhas, 2014):

$$
\begin{aligned}
\dot{\mathrm{D}}_{\text {total }}= & \mathrm{w}_{\text {alfa }} \dot{\mathrm{D}}_{\text {alfa }}+\mathrm{w}_{\text {proton }} \dot{\mathrm{D}}_{\text {proton }}+ \\
& \mathrm{w}_{\text {neutron }} \dot{\mathrm{D}}_{\text {neutron }}+\mathrm{w}_{\gamma} \dot{\mathrm{D}}_{\gamma}
\end{aligned}
$$

Ditotal is the total dose rate, its units are $\mathrm{Gy} / \mathrm{s} ; \mathrm{W}_{\text {alfa }}$ is the radiation weight factor of the alpha; Dalfa is the rate of alpha dosage, its units are $\mathrm{Gy} / \mathrm{s} ; \mathrm{w}_{\text {proton }}$ is the radiation weight factor of protons; $\dot{\mathrm{D}}_{\text {proton }}$ is the proton dose rate, its units are $\mathrm{Gy} / \mathrm{s}$; $\mathrm{w}_{\text {neutron }}$ is the radiation weight factor of neutrons; $\dot{\mathrm{D}}_{\text {neutron }}$ is the dose rate of neutrons, its units are $\mathrm{Gy} / \mathrm{s} ; \mathrm{w}_{\gamma}$ is the radiation weight factor of gamma; And D $\gamma$ is the rate of gamma dose, its units are Gy/s.

Calculation of the total dose rate of each radiation has different contributions as described in Chapter 2 caused by RBE, CBE, and dose reduction factor factors. These differences are characterized by differences in radiation weight factor values. The radiation weight factor value is determined after considering factors affecting biological effects. The value is different depending on the type of radiation used.

Table 3. Raw Factor Weight Ratio Value (Berlianti, 2013; Irhas, 2014)

\begin{tabular}{|l|l|}
\hline Radiation Sources & RBE Factor \\
\hline Alfa & 3,8 (tumor) \\
& 1,3 (soft tissue) \\
\hline Proton & 2 \\
\hline Neutron Scattering & 3,2 \\
\hline Gamma & 1 \\
\hline
\end{tabular}

In the BNCT dose calculation, the absorption dose rate is multiplied by the radiation weight factor to obtain the dose of BNCT. This dose can be said as an isoeffective dose. An isoeffective dose is the dose unit used in clinical cases, which shows the relationship between absorbable doses induced by biological effects on the tissues.

\section{RESULTS AND ANALYSIS}

In this study, the neutron source used was the neutron source of the collimator output on the Kartini Reactor Thermal column, conceptually designed by Fauziah (2013). The collimator uses pure nickel with a thickness of $5 \mathrm{~cm}$ along the collimator wall, aluminum with a thickness of 60 $\mathrm{cm}$ as a moderator, nickel-60 with a thickness of $15 \mathrm{~cm}$ as a neutron filter, bismuth with a thickness of $2 \mathrm{~cm}$ as a gamma ray shield and 6Li2CO3polyethylene with a thickness of $3 \mathrm{~cm}$ as a neutron radiation barrier. The reason why this research uses this design is that its neutron output meets the IAEA recommendations. The drawing of the collimator design and its output can be seen in Figure 5 and Table 2 in the literature review section. The collimator design and the resulting neutron output are simulated using MCNP5. While in this study, the MCNPX was used, so researchers created a new collimator with the same design which yielded results similar to Fauziah collimator design (2013). 


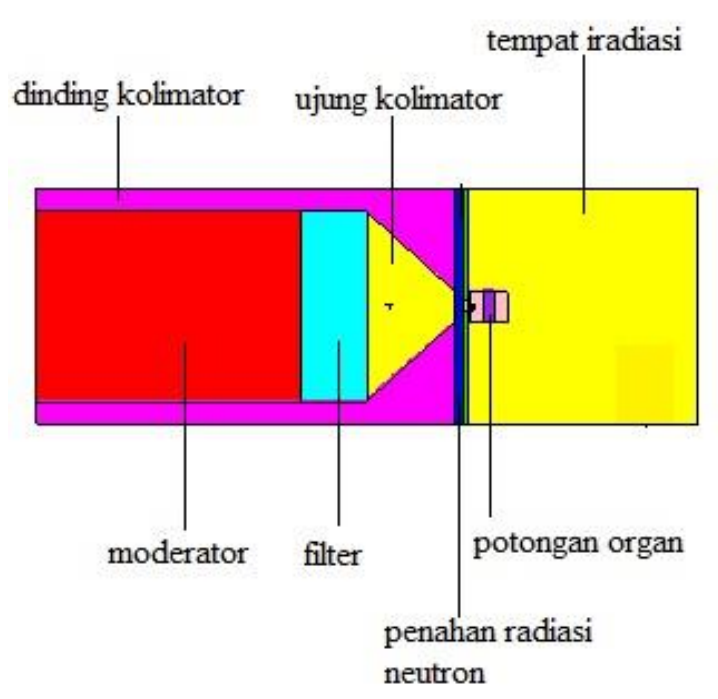

Figure 1. The design of the collimator along with the location of the irradiated organ is viewed from a side viewpoint.

Figure 1 shows the collimator design used in this study along with the irradiated organs seen from the front viewpoint. The purple color shows the collimator wall, a $54 \mathrm{~cm}$ diameter cylinder and uses a pure nickel material of $5 \mathrm{~cm}$ thickness. The section in red shows the neutron moderator, a cylinder with a diameter of $44 \mathrm{~cm}$ and a thickness of $60 \mathrm{~cm}$, and it uses aluminum material. The light blue color shows a neutron filter, a cylinder with a diameter of $44 \mathrm{~cm}$ and a thickness of $15 \mathrm{~cm}$, and uses a nickel-60 material. The yellow color indicates the tip of the collimator and the irradiation site, which contains the air. Dark and green shades show a gamma ray shield and neutron radiation barrier. The pink section shows the upper arm that is affected by melanoma. The arm is in the form of a cylinder and has a diameter of $8.7 \mathrm{~cm}$ in which there is a bone with a diameter of $2.4 \mathrm{~cm}$, muscle tissue and melanoma skin cancer tissue.

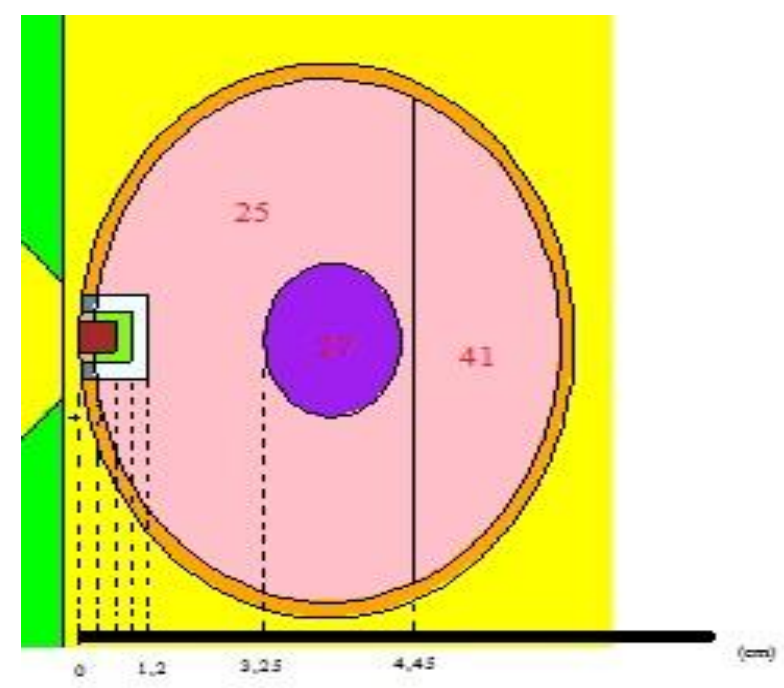

Fig. 2 The Irradiation Organ Model

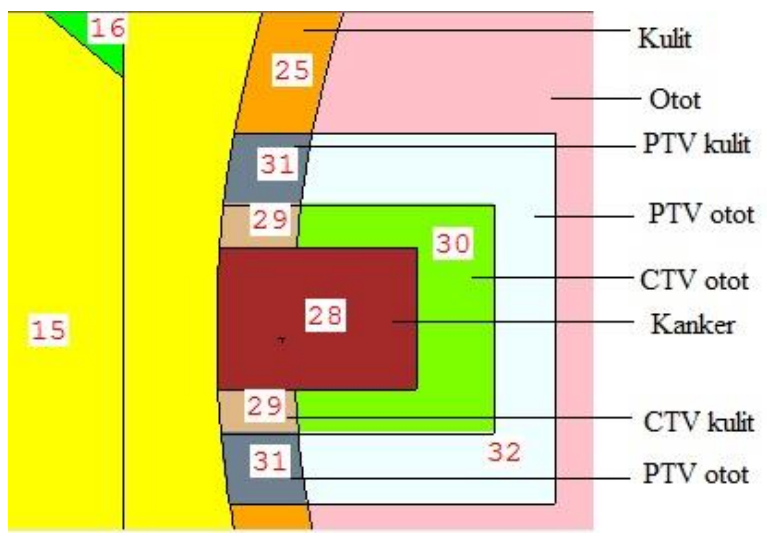

Fig. 3 Skin Cancer Melanoma Model

The input code of MCNPX used to find the value of the collimator output in this study uses a simulation to model the source of radiation (source definition or sdef). Sdef source modeling involves many variables that must be defined. These variables include the type of radiation beam, source form, energy and radiation direction along with its distribution. Each variable is represented by keywords written in the following format:

sdef keyword1 keyword2 keyword3 ...keywordn

The input codes for modeling the sources in this study are:

$$
\begin{array}{rl}
\text { sdef } & \text { sur=2 } \\
\text { vec }=10 & 0 \text { dir }=1 .
\end{array}
$$


The code shows that in the collimator there is a neutron at the point $(0,0,0) ; 0.1 \mathrm{MeV}$ energized; a neutron at the surface boundary (surface) 2; a neutron at the reference vector (1 0 0). In addition, the authors also divide the neutron energies when out of the collimator into 3 energy categories; $\leq 5 \times 10^{-7} \mathrm{MeV}$ is a thermal neutron; $\leq 0.01 \mathrm{MeV}$ is an epithermal neutron; and $\leq 20 \mathrm{MeV}$ is a fast neutron.

Table 4. Result of Fauziah collar eruption and Research Collimator

\begin{tabular}{|c|c|c|}
\hline Parameter & $\begin{array}{l}\text { Fauziah design } \\
\text { collimator }\end{array}$ & $\begin{array}{l}\text { Research } \\
\text { Collimator }\end{array}$ \\
\hline $\begin{array}{l}\text { Thermal neutron } \\
\text { flux } \\
\left(\mathrm{n} \mathrm{cm}^{2} \mathrm{~s}^{-1}\right)\end{array}$ & $1.155 \times 10^{8}$ & $\begin{array}{l}8.31952 \times \\
106\end{array}$ \\
\hline $\begin{array}{l}\text { Epitermal neutron } \\
\text { flux } \\
\left(\mathrm{n} \mathrm{cm}^{2} \mathrm{~s}^{-1}\right)\end{array}$ & $1.65 \times 10^{9}$ & $\begin{array}{l}1.90346 \times \\
109\end{array}$ \\
\hline $\begin{array}{l}\text { The ratio between } \\
\text { thermal and } \\
\text { epithermal flux } \\
\text { neutrons }\end{array}$ & 0.007 & 0.004 \\
\hline $\begin{array}{l}\text { Epidermal neutron } \\
\text { gamma dose rate / } \\
\text { flux density } \\
\left(\mathrm{Gy} \mathrm{cm}^{2} \mathrm{n}^{-1}\right)\end{array}$ & $1.16 \times 10^{-13}$ & $\begin{array}{l}2.515430 \times \\
10^{-14}\end{array}$ \\
\hline
\end{tabular}

In this study, the authors injected 6 variations of boron concentration into cancer tissue, ie $10 \mu \mathrm{g} / \mathrm{g}$ of cancer; $15 \mu \mathrm{g} / \mathrm{g}$ of cancer; $20 \mu \mathrm{g} / \mathrm{g}$ of cancer; $25 \mu \mathrm{g} / \mathrm{g}$ of cancer; $30 \mu \mathrm{g} / \mathrm{g}$ of cancer; And $35 \mu \mathrm{g} / \mathrm{g}$ of cancer. Each boron concentration is performed running MCNPX to obtain the neutron flux value in cancer and other tissues.

Table 5. Neuton flux in every tissue with boron concentration $35 \mu \mathrm{g} / \mathrm{g}$ cancer.

\begin{tabular}{|l|l|l|c|c|}
\hline Tissue & $\begin{array}{l}\text { Cell } \\
\text { number }\end{array}$ & $\begin{array}{l}\text { Depth } \\
(\mathrm{cm})\end{array}$ & $\begin{array}{c}\text { Thermal } \\
\text { neutron flux } \\
(\text { n.cm-2.s-1) }\end{array}$ & $\begin{array}{c}\text { Epithermal } \\
\text { neutron flux } \\
\text { (n.cm-2.s-1) }\end{array}$ \\
\hline cancer & 28 & 0 & $1,84335 \mathrm{E}+09$ & $1,18980 \mathrm{E}+10$ \\
\hline $\begin{array}{l}\text { ctv } \\
\text { skin }\end{array}$ & 29 & 0,2 & $8,20896 \mathrm{E}+09$ & $2,05489 \mathrm{E}+11$ \\
\hline $\begin{array}{l}\text { ptv } \\
\text { skin }\end{array}$ & 31 & 0,2 & $6,96633 \mathrm{E}+09$ & $2,89141 \mathrm{E}+11$ \\
\hline $\begin{array}{l}\text { ctv } \\
\text { muscle }\end{array}$ & 30 & 0,6 & $4,96145 \mathrm{E}+10$ & $2,41593 \mathrm{E}+11$ \\
\hline
\end{tabular}

\begin{tabular}{|l|l|l|c|c|}
\hline Tissue & $\begin{array}{l}\text { Cell } \\
\text { number }\end{array}$ & $\begin{array}{l}\text { Depth } \\
(\mathrm{cm})\end{array}$ & $\begin{array}{c}\text { Thermal } \\
\text { neutron flux } \\
(\text { n.cm-2.s-1) }\end{array}$ & $\begin{array}{c}\text { Epithermal } \\
\text { neutron flux } \\
\text { (n.cm-2.s-1) }\end{array}$ \\
\hline $\begin{array}{l}\text { ptv } \\
\text { muscle }\end{array}$ & 32 & 0,9 & $8,68118 \mathrm{E}+10$ & $2,86912 \mathrm{E}+11$ \\
\hline otot & 26 & 1,2 & $5,47110 \mathrm{E}+11$ & $5,24331 \mathrm{E}+11$ \\
\hline bone & 27 & 3,25 & $4,94017 \mathrm{E}+11$ & $2,26496 \mathrm{E}+11$ \\
\hline slice & 40 & 4,45 & $1,00961 \mathrm{E}+10$ & $2,40921 \mathrm{E}+10$ \\
\hline
\end{tabular}

The thermal and epithermal neutron flux values in the table have almost identical characteristics, i.e. the thermal and epithermal neutron flux values reach the highest point at a depth of $1.2 \mathrm{~cm}$ from the surface of the skin from the direction of the neutron radiation source, i.e., to the muscle tissue. This can be seen in Figure 2 which shows the distribution of neutron flux at a certain depth in the arm organs for the concentration of boron $35 \mu \mathrm{g} / \mathrm{g}$ of cancer.

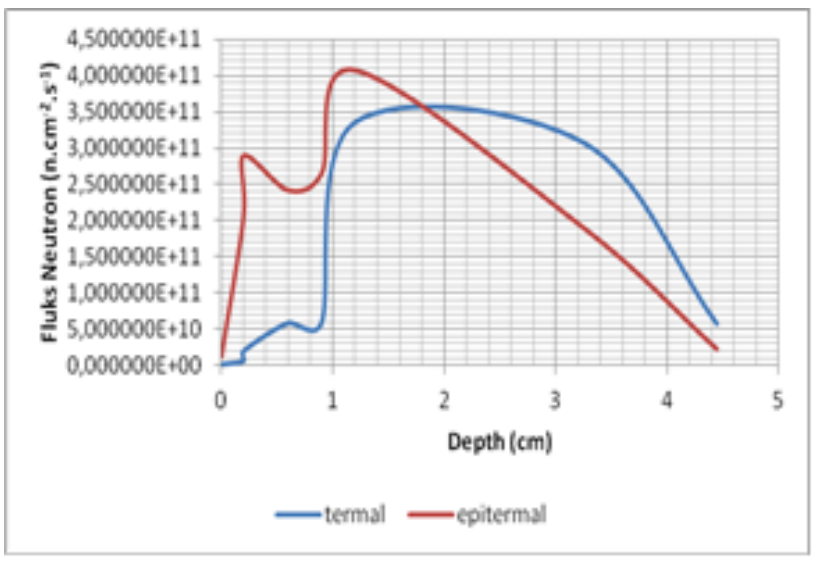

Figure 2. Neutron Flux Distribution in Organs

Figure 2 shows the change in the value of the neutron flux in the organs of the arm within a certain depth. The value of the thermal neutron flux increases at $0 \mathrm{~cm}$ and reaches the highest value at a depth of $1.2 \mathrm{~cm}$ and after a depth of 3.25 $\mathrm{cm}$, the value decreases significantly. Similarly, the flux value of epithermal neutrons has increased from a depth of $0 \mathrm{~cm}$ and reaches the highest value at a depth of $1.2 \mathrm{~cm}$. However, at a depth of $4.45 \mathrm{~cm}$ the value is also still quite high. This suits the theory quite well. Because 
according to the theory the value of thermal neutron flux reaches the highest peak at a depth of 0-2 cm and epithermal neutrons at a depth of $2-8 \mathrm{~cm}$ as shown in Figure 3 (IAEA, 2001).

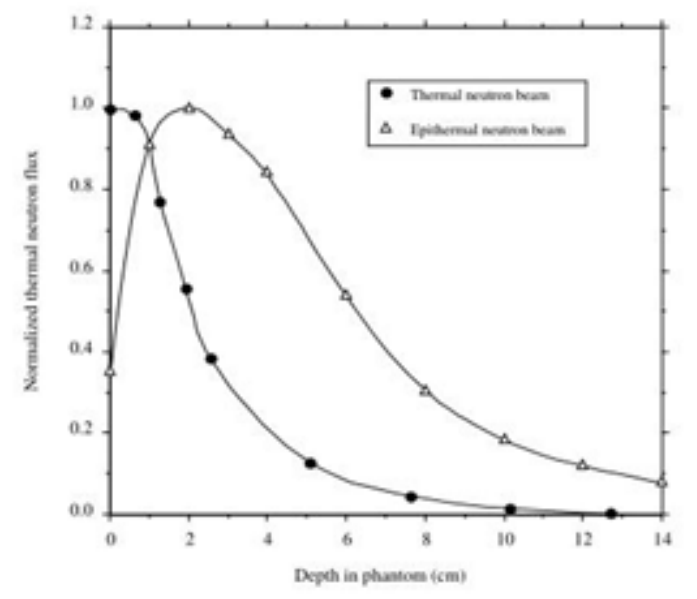

Figure 3. The thermal and epithermal neutron flux distribution curves (IAEA, 2001)

In BNCT dosimetry, there are four components of BNCT dose according to the interaction between neutrons with the body's tissue material. The dose component is the dose of neutron scattering, gamma dose, proton recoil dose and alpha dose. MCNPX output results that can be used directly i.e. thermal neutron flux and thermal neutron scattering dose in cancerous tissue. The value of the thermal neutron flux is used to find the gamma dose rate, proton dose rate and alpha dose rate. The gamma dose rate is derived from the results of the thermal neutron and hydrogen- 1 reactions. The proton rate dose is derived from the thermal neutron catch reaction with nitrogen-14. While the alpha dose rate is derived from the reaction of thermal neutrons and boron-10. The dose rate is multiplied by the radiation weight factor to obtain the total dose rate. The radiation weight factor is the ratio of radiation that causes damage to tissues/organs.
The dose rate for each component of BNCT dose has an increasing effect if boron concentration is increased. When calculating the dose rate, in addition to the thermal neutron flux, the value of the number of atoms is also used. The value of the number of atoms is influenced by the mass of the elements that interact with the thermal neutrons. The mass of the element boron- 10 changes according to its concentration variation as well as the constantly fixed mass of nitrogen and hydrogen affect this process. All calculations regarding the total dose rate are done manually by using the Microsoft Excel application. An example of calculating the total dose rate can be seen in Appendix 3.

In BNCT, doses are used by a single fraction. A single fraction is a way of administering doses directly in one irradiation so it is worth noting the total dose received by healthy tissue. To determine whether the dose rate absorbed by body tissues is safe or not, a total absorption dose rate is used. The total absorption dosage is the result of multiplying the dose rate with irradiation time. The irradiation time is obtained from the minimal dosage of the cancer tissue damaged by the total dose rate (Berlianti, 2013; Setiyadi, 2015). The minimum limit for killing melanoma skin cancer cells is 30-36 Gy (Anand, 2013). In this study, a dose of $30 \mathrm{~Gy}$ was used as a minimum dose to destroy cancer tissue.

time irradiation $=\frac{30(\text { Gy) }}{\text { total dose rate }\left(\frac{G y}{\text { detik }}\right)}$

Each variation of boron concentration for the total dose rate and irradiation time in this study can be seen in table 20. The amount of boron atom concentration required to kill cancer tissue is generally estimated at 109 atoms with a natural abundance of $19.9 \%$ per cell, which translates to about $35 \mu \mathrm{g} / \mathrm{g}$ cancer tissue. So in 
this study the boron concentration used was 10 $\mu \mathrm{g}-35 \mu \mathrm{g}$ per gram of cancer tissue (Zhu et al. 2010).

Table 6. Dose Rate and Irradiation Time on Cancer Network

\begin{tabular}{|c|c|c|c|}
\hline $\begin{array}{c}\text { Boron Concen } \\
\text { tration } \\
(\boldsymbol{\mu g} / \mathrm{g} \text { cancer })\end{array}$ & $\begin{array}{c}\text { Total Dose } \\
\text { rate } \\
(\mathrm{Gy} / \mathrm{s})\end{array}$ & $\begin{array}{c}\text { Time } \\
\text { Irradiation } \\
(\mathrm{s})\end{array}$ & $\begin{array}{c}\text { Time } \\
\text { Irradiation } \\
(\mathrm{min})\end{array}$ \\
\hline 10 & 0,019241 & 1559,176541 & 25,98628 \\
\hline 15 & 0,021854 & 1372,717077 & 22,87862 \\
\hline 20 & 0,022902 & 1309,929895 & 21,83216 \\
\hline 25 & 0,027128 & 1105,885096 & 18,43142 \\
\hline 30 & 0,029766 & 1007,866575 & 16,79778 \\
\hline 35 & 0,034347 & 873,4332847 & 14,55722 \\
\hline
\end{tabular}

From table 22, it can be seen the greater the value of boron concentration used, the greater the value of the total dose rate and the shorter the time required for irradiation.

In order to obtain better results, the suggestions given for the next research are; 1) Making a human geometry intact, not just a piece of organs, 2) Further research should be done on the effect of doses on melanoma skin cancer using a collimator and the actual neutron source of the Kartini Reactor in order to obtain more accurate results, 3) Sampling of data should be more specific by taking data from the hospital for melanoma skin cancer patients.

\section{CONCLUSION}

1. The optimum boron concentration for treating skin cancer melanoma is $35 \mu \mathrm{g} / \mathrm{g}$ cancer which is achieved by considering the dose received by healthy tissue, ctv skin, skin ptv and cancer cells.

2. The time taken to irradiate the melanoma skin cancer tissue is faster with the added concentration of boron used. The shortest time needed for the irradiation of melanoma skin cancer tissue is when a concentration of $35 \mu \mathrm{g} / \mathrm{g}$ of cancer is administered which has an irradiation time of 14.55 minutes.

\section{ACKNOWLEDGEMENT}

The authors would like to express their thanks to those who took roles for the accomplishment of the project, aspesially for Dr. Susilo Widodo as a Head of Center for Accaelerator and Material Process Technology national Nuclear energy Agency (PSTABATAN) for the opportunity given to do this work.

\section{REFERENCES}

Akhadi, Mukhlis. (2001). Dasar-Dasar Proteksi Radiasi. Jakarta: Rinska Cipta. Jakarta.

American Cancer Society. (2013). Cancer Facts \& Figures 2013. Atlanta: American Cancer Society.

American Cancer Society. (2014). Cancer Facts \& Figures 2014. Atlanta: American Cancer Society.

American Cancer Society. (2015). Cancer Facts \& Figures 2015. Atlanta: American Cancer Society.

American Cancer Society. (2016). Cancer Facts \& Figures 2016. Atlanta: American Cancer Society.

American Cancer Society. (2016). Melanoma Skin Cancer. Atlanta: American Cancer Society.

Amin Shokr, A. et al. (2001). Current Status of Neutron Capture Therapy, IAEA-TECDOC1223. Vienna, Austria: International Atomic Energy Agency.

Attix, H. (1986). Introduction to Radiologycal Physics and Radiation Dosimetry. Madsion:University of Wilscosin Medical Schoo.

Australia Cancer Council. (2008). Melanoma-An Aide Memoire to Assist Diagnosis. Diakses dari http:// www.cancer.org.au/ aboutcancer/types-of-cancer/skin- 
cancer/melanoma.html pada tanggal 11 September 2014.

Azamris. (2011). Kanker Kulit di Bangsal Bedah RS Dr. M. Djamil Padang Januari 2002 - Maret 2007. CDK 183/Vol.38 no.2/Maret - April 2011. Hlm. 109-110.

Bapeten. (2015). Efek Radiasi pada Sistem

Biologi. Diakses dari ansn.bapeten.go.id/files/ins_Efek_Biolog i.pdf. pada tanggal 7 Mei 2016.

Bapeten.(2015).Dosimetri.Diakses dari ansn.bapeten.go.id/files/ins_dosimetri.pd f. pada tanggal 7 Mei 2016.

Berlianti, Dwi. (2013). Analisis Dosis di Organ Kritis pada Terapi Glioblastoma dengan Boron Neutron Capture Therapy Menggunakan Metode Simulasi MCNP5. Skripsi: Fakultas Teknik - Universitas Gajah Mada.

Booth, T.E. et al. (2003). MCNP - A General Monte Carlo N-Particle Transport Code, Version 5, volume I: User's Guide. New Mexico: Los Alamos National Laboratory.

Cember H, Johnson T. (2009). Health Physics. New York: The Mc Graw-Hill Compaines. New York: The Mc GrawHill Compaines.

Deng, Li. et al. (2011). The Dosimetry Calculation for Boron Neutron Capture Therapy. Diagnostic Techniques and Surgical Management of Brain Tumors. Hlm. 173-198.

Denise B. Pelowitz (ed). (2008). MCNPXTM User's Manual. Amerika: Los Alamos National Laboratory.

Flores, F. Fernanda. et al. (2012). Boron Uptake in Normal Melanocytes and Melanoma Cells and Boron Biodistrubution Study in Mice Bearing B16F10 Melanoma for Boron Neutron Capture Therapy. Jurnal Radiat Environ Biophsy. 51. Hlm. 319-329.

Fauziah, Nina. (2013). A Conceptual Design of Neutron Collimator in Thermal Column of Kartini Research Reactor of Boron Neutron Capture Therapy. Skripsi:
Fakultas Teknik - Universitas Gajah Mada. Hudi Hastowo dan Iyos R. Subki. (1999). Boron Neutron Capture Therapy (BNCT), Status Teknologi Saat ini dan Kemungkinan Penggunaanyya di Indonesia. Prosiding Pertemuan don Presentasi /lmiah P3TMBATAN, Yogyakarta 14 -15 Juli 1999 Buku I. Hlm. 107-115.

IAEA. (2001). Current Status of Neutron Capture Therapy. Wina:IAEA.

Irhas. (2014). Dosimetri Boron Neutron Capture Therapy pada Kanker Hati (Hepatocellular Carcinoma) Menggunakan MCNP-Code dengan Sumber Neutron dari Kolom Termal Reaktor Kartini. Skripsi: Fakultas Teknik Universitas Gajah Mada.

Harling, Otto K. dan Riley, Kent J. (2012). Fission Reactor-Based Irradiation Facillities for Neutron Capture Therapy-Malignant Melanoma. Neutron Capture Therapy. Hlm. 19-40.

Hendricks, John S. et al. (2008). MCNPX 2.6.0 EXTENSIONS: Los Alamos National Laboratory.

John W. Hopewell, et al. (2012). Boron Neutron Capture Therapy Application of Radiobiological Principles. Capture Therapy. Jurnal Neutron Capture Therapy. W.A.G. Sauerwein et al. (eds.). Hlm. 329358.

Judith F. Briesmeister (ed). (2000). MCNPTMA General Monte Carlo N-Particle Transport Code Version 4C. Los Alamos National Laboratory.

Junichi Hiratsuka dan Hiroshi Fukuda. (2012). Malignant Melanoma. Jurnal Neutron Capture Therapy. W.A.G. Sauerwein et al. (eds.). Hlm. 433-448.

Muslih, Ilma. (2015). Dasar-Dasar Pemrograman MCNPX. Yogyakarta:PSTA-BATAN.

Moeloek, Nila dan Lukiarti Rukmini. (2011). Indonesia Cancer Foundation. Jakarta: Yayasan Kanker Indonesia. Jakarta.

McConn et al. (2011). Compenidium of Material Composition Data for Radiation Transport Modeling. Washington: Pacific Northwest National Laboratory. 
Oemiati, Ratih. Rahajeng, Ekowati. dan Kristanto, Antonius Yudi. (2011). Prevalensi Tumor dan Beberapa Faktor yang Mempengaruhinya di Indonesia. Buletin Penelitian Kesehatan Vol. 39 No. 4. Hlm. 190-204.

PTAPB BATAN. (2013). Reaktor Kartini. Yogyakarta: BATAN Yogyakarta.

Rasito. (2013). Pengenalan MCNP untuk Pengkajian Dosis. Pusat Pendidikan dan dan Pelatihan BATAN.

Savitskaya, E.N. dan Sannikov, A.V. (1995). High Energy Neutron and Proton Kerma Factors for Different Element. Radiant Protection Dosimetry Vol. 60 No. 2. Hlm. 135-146.

Setiyadi, A. (2015). Dosis Boron Neutron Capture Therapy (BNCT) pada Kanker Kulit (Melanoma Maligna) Menggunakan MCNPX-Code dengan Sumber Neutron dari Beamport Tembus Reaktor Kartini. Skripsi.Yogyakarta: Universitas Negeri Yogyakarta.

Shultis, J.K. and Faw, R.E. (2011). An MCNP Primer. Manhattan: Kansas State University.

Wahyuningsih, D. (2014). Optimasi Desain Kolimator untuk Uji In Vivo Boron Neutron Capture Therapy (BNCT) pada Beamport Tembus Reaktor Kartini Menggunkan Simulasi Monte Carlo N Particle 5 (MCNP5). Tesis. Yogyakarta: Universitas Gajah Mada.

Wang, Yu. et al. (2013). New type of neutron image scintillator based on $\mathrm{H} 3$ 10BO3/ZnS(Ag). Physics Procedia Vol. 43. Hlm. 216-222.

Wiyatmo, Yusman. (2009). Fisika Nulkir Dalam Telaah Semi-klasik dan Kuantum. Yogyakarta: Pustaka Pelajar. Yoyakarta.

Wiryosimin, S. (1996). Mengenal Asas Proteksi Radiasi. Bandung: ITB. Bandung.

Wolfgang A.G. Sauerwein. (2012). Principle and Root of Neutron Capture Therapy. Jurnal Neutron Capture Therapy. Hlm. 116.
Wolfgang A.G. Sauerwein, Pierre M. Bet, dan Andrea Wittig. (2012). Drugs for BNCT: BSH and BPA. Jurnal Neutron Capture Therapy. Hlm. 117-140.

World Health Organization. (2014). Cancer Country Profiles 2014. World Health Organization. Jakarta, Indonesi 